https://doi.org/10.52058/2786-4952 -2021-4(4)-387-397

Синишина Вікторія Михайлівна кандидат психологічних наук, доктор педагогічних наук, доцент, доцент кафедри психології, Державний вищий навчальний заклад «Ужгородський національний університет», пл. Народна, 3, м. Ужгород, 88000, тел.: (095) 540-06-13, e-mail: vsinishina@ukr.net, https://orcid.org/0000-0002-7993-1638

Яковицька Лада Савеліївна доктор психологічних наук, доцент, професор кафедри авіаційної психології, Національний Авіаційний Університет, пр. Космонавта Комарова 1, м. Київ, 03058, тел.: (099) 444-14-84, e-mail: lada.yakovytska@nau.edu.ua, https://orcid.org/0000-0002-6858-7704

\title{
СУБ'ЄКТНІСТЬ СТУДЕНТА-ПСИХОЛОГА ЯК ОСНОВА ЙОГО САМОРЕАЛІЗАЦІї
}

Анотація. У статті зроблена спроба з'ясувати роль суб'єктності у розвитку самореалізації майбутніх психологів в умовах вищого навчального закладу. Здійснений огляд наукових публікацій за обраною темою. Вказано, що головним інструментом професійної діяльності психолога $\epsilon$ він сам та перш за все його особистість, що предбачає безперервне особистісно-професійне зростання і потребує високого рівня активності, саморегуляції та самостійності. Визначено, що можливість самореалізації особистості це постійний саморозвиток; вміння планувати й здійснювати вчинки, відповідні загальнолюдським цінностям; мобілізація себе на подолання труднощів; об'єктивне оцінювання своїх сильних і слабких сторін, рівня своєї готовності до нових, більш складних дій та вчинків. Визначено, що самореалізація спрямовує фахівця на власне вдосконалення впродовж життя, розглядає професіоналізм як вищу сходинку в розвитку особистості, скеровує на розкриття творчого потенціалу під час суб'єктсубєктної взаємодії з викладачами та під час виконання фахово-зорієнтованих задач. Вказано, що процес розвитку суб'єктності майбутніх практичних психологів - це взаємодія суб'єктного потенціалу, суб'єктної активності і професійної суб'єктності, що виявляють передумову, механізм і результат розвитку. З'ясована необхідність саморозвитку, самоосвіти та рефлексії особистісних якостей, власних професійних згань, умінь та навичок. Визначено, що для розвитку суб'єктності як чинника самореалізації необхідні відповідні передумови i умови: актуалізація суб'єктного досвіду студентів i його включення в зміст фахової підготовки, компетентність викладачів, які здійснюють професійну підготовку студентів 3 метою їх максимальної самореалізації; діалогічна взаємодія суб'єктів навчального процесу; 
використання особистісно-зорієтованого підходу до навчання. Наведено приклади методів розвитку суб'єктності у процесі фахової підготовки психологів в умовах вищого навчального закладу.

Ключові слова: суб’єктність особистості, особистість майбутнього психолога, професійна та особистісна самореалізація, вища освіта, підготовка майбутніх психологів, особистісно-зорієнтована освіта, рефлексія.

Synyshyna Viktoriia Mykhailivna Doctor of Pedagogical Sciences, Associate Professor, Associate Professor of the Department of Psychology of the State institution of higher education «Uzhhorod National University», Uzhhorod, 88000, Narodna Squa., 3, tel.: (095) 540-06-13, e-mail: vsinishina@ukr.net, https://orcid.org/0000-0002-7993-1638

Yakovytska Lada Saveliivna Doctor of Psychological Sciences, Professor Aviation Psychology Department of National Aviation University, Sviatoslav Huzar Ave., 1, Kyiv, 03058. tel.: (099) 444-14-84, e-mail: lada.yakovytska@nau.edu.ua, https://orcid.org/0000-0002-6858-7704

\section{SUBJECTITY OF A STUDENT-PSYCHOLOGIST AS THE BASIS OF HIS SELF-REALIZATION}

Abstract. The article attempts to clarify the role of subjectity in the development of self-realization of future psychologists in the conditions of the institution of higher education. Review of scientific works on the selected topic has been done. It has been stated that the main instrument of a psychologist's professional activity is himself and, first of all, his personality, which provides a continuous personal and professional growth and needs a high level of activity, self-regulation and independence. It has been defined that the possibility of realization of personality is a constant self-development; ability to plan and perform actions corresponding to common human values; mobilizing oneself to overcome difficulties; objective evaluating own strong and weak sides, the level of readiness for new, more complicated actions and deeds. It has been determined that self-realization directs the specialist to personal improvement during the whole life, considers professionalism as a higher step in the development of personality, aims to the disclosure of creative potential during the subject-subject interaction with lecturers and during the performance of professionally-oriented tasks. It has been noted that the process of development of subjectity of future practical psychologists - is an interaction of a subject potential, subject activity and professional subjectity, revealing the precondition, mechanism and result of development. The necessity in self-development, self education and reflection of personality qualities, own professional knowledge, abilities and skills has been clarified. It has been identified that for the development of subjectity as a factor of self-realization the appropriate preconditions and conditions are required: actualization of subjectity of students' experience and its inclusion into the content of vocational training, 
competence of lecturers, who carry out vocational training of students for the purpose of their maximum self-realization; dialogic interaction of the subjects of educational process; using personality-oriented approach for study. Examples of methods of the development of subjectity in the process of vocational training of psychologists in the conditions of the institution of higher education have been given.

Keywords: subjectity of personality, personality of future psychologist, professional and personal self-realization, higher education, training of future psychologists, personality-oriented education, reflection.

Постановка проблеми. Постмодерна епоха, яка характеризується переходом від індустріального до інформаційного суспільства, призвела до трансформацій у всіх сферах життя. Психологічна освіта не $\epsilon$ винятком і нерозривно взаємопов'язана з нагальними процесами у суспільстві. Існуюча раніше система фахової підготовки майбутніх практичних психологів, на думку В. Панка, перестала відповідати реальності, тим істотним змінам, які відбулися за останні десятиліття і відбуваються щодня. Висока динамічність життя XXI століття вступає в конфлікт з консервативністю системи психологічної освіти, яка була створена в іншу епоху, в інших економічних умовах [1, с. 146].

Підготовку фахівців, майбутніх психологів-практиків, здатних працювати в нових економічних, технологічних, інформаційних умовах, можливо зреалізувати тільки в умовах особистісно-зорієнтованої парадигми, яка спрямовує психолога на успішну як особистісну, так i професійну самореалізацію, розкриття потенційних можливостей через відхід від позиції об'єкта впливу освітньої системи до активної позиції суб'єкта побудови власної особистісно-професійної траєкторії. Водночас розвивальна особистіснозорієнтована парадигма освіти, незважаючи на іiі прогресивність та загальновизнаність, часто має формально-декларативний характер. Перехід від декларування до втілення ідей особистісно-зорієнтованої освіти можливий лише за наявності реальних моделей організації навчального процесу з урахуванням специфіки професії, що освоюється психологом.

Ведучи пошук ефективних шляхів реформування змісту, форм і методів підготовки практикуючих психологів, В. Панок окреслює специфічні особливості їхньої професійної підготовки в закладах вищої освіти: не кожен може працювати психологом, тому процес професійної підготовки повинен спрямовуватися на формування професійно важливих рис особистості фахівця (психологічний світогляд, спрямованість особистості, навички саморегуляції, розвиток професійної інтуїції, специфічна Я-концепція, альтруїстичні настанови тощо) [2, с. 19].

Специфічними характеристиками професійної діяльності психолога $є$ ii яскраво виражена суб'єкт-суб'єктна спрямованість та необхідність ціннісного ставлення до суб'єктивної реальності іншої людини. Для майбутнього психологапрактика власна особистість $є$ важливим інструментом дослідницької і 
Журнал«Герспектвиитаіноовації наукиљ

(Серія«Гедагогіка», Серія«Гцихологія», Серія«Медицинв»

№4(4) 2021

практичної діяльності. Підтвердження цьому й знаходимо у дослідженні Г. Строй, яка зазначає, що, незважаючи на те, чи це психотерапія гуманістичного спрямування чи експериментальне вивчення мотивації соціальної поведінки, особистісні характеристики практичних психологів обов'язково позначаються на результатах і способах їхньої діяльності [3, с. 10].

Відтак головним інструментом професійної діяльності психолога є він сам та перш за все його особистість, що предбачає безперервне особистіснопрофесійне зростання і потребує високого рівня активності, саморегуляції та самостійності. Аналіз специфіки даної професії та практики підготовки психологів у вузі дозволяє зробити висновок про значні розбіжності вимог до майбутнього фахівця та освітньої ситуації, що склалася. Вказана розбіжність обумовлює необхідність інноваційних змін у підготовці психолога, магістральним напрямом якої має стати сприяння розвитку суб'єктності особистості студента як чинника успішної самореалізації.

Аналіз останніх досліджень і публікацій. В дослідженнях вчених А. Деркач, Ю. Журат, С. Кузікова, В. Ягупова розглядаються теоретикометодологічні основи формування суб'єктності студентів, де визначається активна роль внутрішніх чинників у визначенні зовнішніх умов як навчальної, так і професійної діяльності.

Проблема самореалізації та самоактуалізації в навчальній i навчальнопрофесійній діяльності знаходить своє вирішення в роботах О. Городілової, В. Міхеєва, М. Молоканова, Н. Петрової, І. Туркової, Т. Соломки, С. Ященко та ін. Окремі аспекти розвитку професійних здібностей, особливостей самовизначення, самореалізації та самоактуалізації висвітлено в роботах В. Міхеєва, М. Молоканова, В. Фокіна, Н. Щербакової, С. Ященко та ін. Ідея суб'єктності як чинника самореалізації особистості майбутнього психолога в сучасній психологічній науці розглядається Н. Антоновою, Н. Старинською, К. Мілютіною, В.Татенко та іншими науковцями. Положення про активність та самореалізацію суб'єкта набули широкого поширення і стали основою численних теоретичних та експериментальних досліджень. Проте у сучасній психологічній науці маловивченими залишаються питання суб'єктності студента як необхідної умови самореалізації. Розвиток суб'єктності студентів-психологів передбачає сформованість позиції суб'єкта навчально-професійної діяльності. Така позиція визначається наявністю високого рівня усвідомленості цілей власної самореалізації. Незважаючи на те, що самореалізація $\epsilon$ найважливішим параметром суб'єктності особистості, даний феномен також недостатньо вивчений у психологічній науці.

Мета статті - полягає в обгрунтуванні теоретичних та практичних основ суб'єктності студента-психолога як основи його самореалізації в умовах вищого навчального закладу.

Виклад основного матеріалу. Одне 3 найважливіших завдань сучасних реформ - створити таку систему фахової підготовки майбутніх практичних 
психологів, яка поєднуватиме в собі спрямованість освітнього процесу на розвиток суб'єктності студентів-психологів, що $є$ умовою успішної самореалізації; становлення спрямованості майбутніх практичних психологів на самопізнання, що передбачає відкритість до змін, творче ставлення до життя.

Відтак, представники наукового напряму гуманістичної психології пропонують шляхи подолання перешкод самореалізації: акцент на справжньому в житті; вибір зростання й розвитку серед усього розмаїття виборів; позбавлення від хибних уявлень про себе, розуміння того, що не є твоїми потенційностями; відмова від «повинен», від відповідності очікуванням і догоджання іншим; відповідальність і керівництво собою; бажання бути процесом і відкритість досвіду; прийняття інших, цінності їхнього досвіду; довіра своєму «Я» [4].

Бодальов О. можливість самореалізації особистості розуміє як постійний саморозвиток; вміння планувати й здійснювати вчинки, відповідні загальнолюдським цінностям; мобілізацію себе на подолання труднощів; об'єктивне оцінювання своїх сильних і слабких сторін, рівня своєї готовності до нових, більш складних дій та вчинків [5].

Поряд науковцями висувається думка про потенціал самореалізації особистості. На думку М.А. Садової, потенціал самореалізації особистості $\epsilon$ динамічним інтегративним утворенням, яке визначає ресурсні можливості розвитку людини та їі здатність до оволодіння й продуктивного залучення своїх можливостей у різних видах діяльності [6]. Суб'єктність, соціальність і діяльність С.О. Тетенов, І.С. Морозова виокремлюють як основні чинники, що визначають розвиток особистості й безпосередньо впливають на рівень самореалізації. Становлення суб'єктності особистості охоплює виділення себе як суб'єкта, формування самооцінки, образу «Я», самоприйняття і як результат розвитку самосвідомості формування Самості [7].

На думку Н. Старинської, професійна практична діяльність психолога $\epsilon$ особливим видом соціальної активності, де узагальнені ідеї щодо цінності людини гранично конкретизуються і персоніфікуються в їхніх словах і діях, спрямованих на Іншого. В такому випадку психолог власними професійними діями створює образ Іншого для тих людей, з якими він працює [8, с. 61]. Відтак, у межах руху до гуманізації сучасного суспільства, особистість, яка виявляє якості актуалізатора, найуспішніше здатна впоратися із завданням створення оптимістичного персоніфікованого образу Іншого. 3 огляду на це, особливістю підготовки майбутніх практичних психологів у ЗВО є спрямованість освітнього процесу на розвиток суб'єктності студентів-психологів. Випускники психологічних факультетів 3ВО не завжди озброєні знанням того, як у власній професійній діяльності розвивати суб'єктність. Водночас саме розвиток суб'єктності особистості, як справедливо вказує Н. Антонова, сприяє розширенню психологічного поля, ускладнення структури і змісту діяльності, можливостей самореалізації [Error! Reference source not found., c. 216].

Ці завдання майбутні психологи повиннні вміти ставити і вирішувати, 
Журнал«Герспективита інновації науки

(Серія«Гедагогіка»), Серія «Гиихологія», Серія «Медицинв»

№4(4) 2021

постійно рефлексуючи рівень власного просування до «акме». Нарощування суб'єктності в межах освітнього процесу у ЗВО забезпечується розвитком усіх здібностей i можливостей, зростанням самосвідомості, саморозуміння i самовизначення, що розширюють суб'єктний потенціал i забезпечують формування суб'єктної позиції. Майбутні психологи повинні розуміти, що розвиток суб'єктності не відбувається самовільно, що вона виникає на певному рівні саморозвитку, який визначає актуалізацію їхніх потреб і готовність іiі виявляти. Самореалізація задає сенсозміст акмеологічного розвитку, який передбачає поступове, однак постійне зростання-розвиток в творчому самовираженні.

Процес розвитку суб'єктності майбутніх практичних психологів I. Краснощеченко трактує як взаємодію суб'єктного потенціалу, суб'єктної активності і професійної суб'єктності, що виявляють, відповідно, вихідну підставу (передумову), механізм і результат розвитку. Їм відповідають певні внутрішні (психологічні) причини й умови та зовнішні (соціокультурні та професійні) вимоги та чинники [9, с. 187].

Становлення і розвиток суб'єктності майбутніх психологів, за визначенням О. Митник, є інтегральним, динамічним процесом, який характеризується новоутвореннями, що протікає під впливом комплексу особливостей, аксіологічного, змістовного та суб'єктного наповнення освітнього середовища ЗВО та його можливостей, щодо вибору форм і способів суб'єктної активності майбутнім психологом [10, с. 38]. Цей процес відбувається в межах реалізації власної конструктивної діяльності студента, самопізнання, самодетермінації, саморозвитку, самовдосконалення, самореалізації як суб'єкта життєдіяльності, суб'єкта професійної спільноти, суб'єкта квазі- і власне професійної діяльності.

Основними механізмами процесу становлення і розвитку професійної суб'єктності майбутніх практичних психологів, як доцільно зазначає К. Мілютіна, є: ідентифікація 3 навчально-професійним співтовариством на молодших курсах і професійним співтовариством - на старших; рефлексія та самопізнання; інтеріоризація змісту психологічної освіти в межах освітньої програми спеціальності, способів діяльності, взаємовідносин, професійних цінностей; екстериоризація - застосування отриманих знань в квазіпрофесійній діяльності, взаєминах 3 іншими; цілепокладання особистісно-професійного становлення і розвитку на кожній стадії; саморозвиток, самодетермінація та самореалізація в освітньому процесі, в умовах практики і самостійної професійної діяльності [11, с. 365].

Професіографічний аналіз діяльності майбутніх психологів дав нам змогу упевнитися, що для їхньої фахової підготовки у закладах вищої освіти необхідним є:

- підтримка мотиваційної спрямованості студентів на самопізнання, самовдосконалення й самореалізацію та самоактуалізацію; 
- створення умов для креативного, творчого, позитивного і гуманістичного ставлення студентів-психологів до себе і до оточуючих людей;

- розвиток в освітньому процесі професійно та особистісно значущих якостей: інтелектуальних, комунікативних, емоційно-чуттєвих, мотиваційновольових, духовно-моральних;

- формування навичок здійснення функцій щодо підтримки процесу діалогу 3 клієнтом на основі довіри, присутності, рефлексувань, усвідомлення, відповідальності.

Відповідно, важливо врахувати, що теорія і практика, розвиток знань та вмінь, є, безумовно, необхідним фундаментом фахової підготовки майбутніх психологів у ЗВО. Але вони не вичерпують наявних можливостей формування готовності до надання психологічної допомоги, оскільки для майбутніх психологів вельми важливим $є$ постійна увага до власної особистості, світогляду, до себе і до навколишнього світу. Тому самореалізація особистості студента у навчально-професійної діяльності $є$ динамічна соціальна взаємодія у рамках навчально-професійної сфери, що сприяє актуалізації та розвитку потенційних можливостей студента при забезпеченні педагогічних умов.

Для реалізації вищевказаного в процесі навчання необхідні відповідні передумови i умови: актуалізація суб'єктного досвіду студентів і його включення в зміст фахової підготовки, компетентність викладачів, які здійснюють професійну підготовку студентів 3 метою їх максимальної самореалізації; діалогічна взаємодія суб'єктів навчального процесу; використання в ході навчання інтерактивних методів навчання. Підвищення рівня самореалізації студентів у навчально-професійній діяльності забезпечується взаємодією викладача і студентів на рефлексивному рівні.

Це пов'язано, на наш погляд, перш за все 3 тим, що реалізувати себе майбутній фахівець може тільки в процесі тієї чи іншої соціальної взаємодії та діяльності.

Так, професійно-освітнє середовище значною мірою визначає особистісний розвиток і самореалізацію студентів. I подібно тому, як в діаді «психолог консультант - клієнт» важливі взаємини, засновані на індивідуальних особливостях обох сторін, так і в діаді «викладач - студент» індивідуальні особливості кожного з них відіграють значну роль, а взаємодія між ними несе в собі елементи психотерапевтичного впливу. [12, с. 16]. Результат цієї взаємодії значною мірою залежить від індивідуальних особливостей обох сторін. Діалог, який між ними виникає, розкриває психологічні характеристики, а також особливості індивідуальності кожного з учасників діалогу.

У фаховій підготовці майбутніх психологів особистісний, емоційний вплив викладача набуває особливо важливого значення. 3 одного боку, студент, спілкуючись 3 викладачем, отримує досвід взаємодії 3 іншою людиною, рефлексії, емпатії. 3 іншого - з'являється можливість активного звернення до власного суб'єктивного досвіду, що сприяє рефлексії й усвідомленому 
сприйняттю думок, почуттів, бажань, здібностей. Завдяки цьому студенти навчаються розуміти i приймати себе, піклуватися про себе i взаємини 3 оточуючими на основі вільного вибору, що, безперечно, сприяє як особистісній, так i професійній самореалізації, позаяк шляхи подолання перешкод самоактуалізації - це, в першу чергу, - вільний вибір серед усього розмаїття виборів; позбавлення від хибних уявлень про себе, розуміння того, що не є твоїми потенційностями; прийняття інших, цінності їхнього досвіду; довіра своєму «Я». Відповідно суб'єктові досить здійснити важливий вибір, прийняти правильне рішення, а його реалізація буде гарантована відкритістю зовнішнього світу.

Для успішності такої психологічної взаємодії зусилля викладача повинні спрямовуватися на підвищення усвідомленості і відповідальності студентів. Необхідно, щоб відносини між викладачем та студентами були тим грунтом, на якому в ситуації взаємної зацікавленості та довіри, щирості і прийняття - у студентів розвивалася здатність до довіри і прийняття інших людей, необхідна для психологів. Умовами створення таких відносин $є$ індивідуальні установки студентів та їх особистістні якості та риси: передусім це безоціночне, шанобливе, доброзичливе, довірливе ставлення до Іншого, а також конгруентність, тобто здатність бути самим собою в процесі міжособистісної взаємодії.

Становлення фахівців в сфері практичної психології та рівень їх самореалізації визначається активним характером взаємодії, оскільки саме в цьому процесі закладається фундамент формування особистості, здатної підтримати іншу людину, що знаходиться в кризовій ситуації. Наприклад, навчаючи, викладач в ситуації «тут і тепер» на основі усвідомлення власних цілей, намірів, думок, почуттів і дій, підтримуючи постійний контакт зі студентами, стимулює їхню залученість у процес взаємодії.

У проведенні різних навчальних занять (лекцій, семінарів, тренінгів) викладач може усвідомлено збільшувати або зменшувати міру власного впливу на студентів, узгоджуючи його з контекстом навчання і таким чином сприяти розвитку суб'єктності як основного чинника самореалізації.

Так, у процесі вивчення психологічних дисциплін варто застосовувати методи інтерактивного навчання та особистісно-зорієнтований підхід до навчання, які мотивують студента до самостійності, творчого мислення, гнучкості та толерантності у межах суб'єкт-суб'єктної взаємодії. До прикладу, застосовуючи метод балінт-групи, студенти мають змогу засумніватися у знаннях та вміннях або навпаки повірити у власні сили, побачити свої сильні сторони. Працюючи разом над формуванням вміння аналізувати почуття, керувати почуттями, давати їм назву і знати як їх контролювати та поводитись 3 емоціями - балінт-група розвиває у молодих фахівців навички взаємодії, вміння відчувати клієнта, краще розуміти себе, позбавлятися від контрпереносів, в результаті адекватно надавати допомогу.

Окрім того, балінт-група формує відчуття взаємодії у межах толерантності. Те, що викликає сором щодо відсутності навичок у майбутніх фахівців, у 
балінтових групах коригується асертивністю, взаємодопомогою та відкритістю взаємодії. Вище ми вказували, що одним із внутрішніх чинників успішної професійної діяльності, відтак і самореалізації, є особистісний чинник. У балінтгрупі саме рефлексивні навички зумовлюють професійну та особистісну ідентичність, яка охоплює професійні знання, вміння і навички, а також уявлення про себе як суб'єкта власної діяльності. Тому можна констатувати, що балінтові групи є для студентів акмеологічною подією, яка завжди супроводжується позитивною зміною особистісної та професійної я-концепцій, що сприяє особистісно-професійній самореалізації майбутніх психологів.

Для створення ефективних умов щодо усвідомлення потреб, цілей, мотивів самореалізації студентам можна запропонувати розроблену нами проективну методику «Опис життєвого шляху успішного психолога». Студентам пропонується описати життєвий шлях, ідентифікуючи себе у ролі успішного психолога. Опрацювання результатів відбувається за контент-аналізом опису за такими індикаторами:

- самореалізація у всіх сферах життя;

- самореалізація у професійній діяльності;

- самореалізація в особистісній сфері;

- самореалізація в когнітивній (предметні компетенції);

- вертикальна кар'єра.

Також можна запропонувати студентам протягом 20 сек. висловлювати власну думку про власні здобутки після кожного інтерактивного заняття. Для вироблення вмінь рефлексувати доцільно запропонувати студентам відповіді на запитання: «Що я дізнався, зрозумів, навчився на занятті? Найбільший мій успіх - це... Найбільші труднощі я відчув ...Я не вмів, а тепер умію ...» тощо.

Отже, розвиток суб'єктності як чинника підвищення рівня особистісної та професійної самореалізації майбутніх психологів під час їх професійної підготовки має широкий арсенал потенційних можливостей та залежить від їх ефективного та продуктивного психолого-педагогічного забезпечення в умовах вищого навчального закладу.

Висновки. Узагальнюючи вищевказане, можемо зробити висновок, що більшість професіоналів у сфері психології визнають положення про те, що головним інструментом в роботі психолога є його особистість. Надати якісну психологічну допомогу зможе лише той фахівець, який сам добре розуміє себе та орієнтується у власній особистості, має чітке уявлення щодо власних як слабких, так і сильних сторін, націлений на самореалізацію та саморозвиток. Від рівня розвитку особистісно-професійної самореалізації психологів залежить якість і ефективність послуг, які вони надають.

Самореалізація як об'єктивне явище можлива лише за умови розвитку суб'єктності, а саме коли майбутні психологи за власним вибором та усвідомленим бажанням активно починають діяти, регулюючи власну навчально-професійну поведінку таким чином, щоб «придушувати небажані» та 
посилювати позитивні як особистісні, так і професійні мотиви самоактуалізації та самореалізації, коли рівень розвитку свідомості породжує у студентів потребу пізнати себе як особистість та майбутнього фахівця.

Таким чином, в умовах реформування психологічної освіти у ЗВО відбувається активна діяльнісна переорієнтація практичного психолога, здатного не лише до концептуального мислення, а й до розкриття і реалізації власного професійно-особистісного потенціалу. Перспективою подальших досліджень вбачаємо емпіричне дослідження психологічних особливостей самореалізації студентів в умовах вищого навчального закладу.

\section{Лimepamypa:}

1. Основи практичної психології: підручник для студентів вищих навчальних закладів / за заг. ред. В. Панка. К.: Либідь, 2006. 536 с.

2. Панок В. Реформування змісту, форм і методів підготовки практикуючих психологів як нагальна вимога суспільної практики. Проблеми підготовки $i$ підвищення кваліфрікаціï практичних психологів у вищих навчальних закладах. 2002. Вип. 11. С. 18-28.

3. Строй Г. В. Формирование системы ценностных ориентаций будущих практических психологов в процессе обучения: автореф. дисс. ... канд. психол. наук: 19.00 .07 / Ставропольский госуд. ун-тет. Ставрополь, 2014. 24 с.

4. Маслоу А. По направлению к психологии бытия. М.: Изд-во ЭКСМО-ПРЕСС, 2002. 158 с.

5. Бодалев А.А. Как становятся великими или выдающимися. М.: Изд-во Института Психотерапии, 2003. 287 с.

6. Садова М.А. Психологічні складові потенціалу самореалізації особистості: автореф. дис. на здобуття наук. ступеня канд.. психол. наук: спец. 19.00.01 “Загальна психологія, історія психологіі”" / М.А. Садова. Луцьк, 2010. 14 с.

7. Тетенов С.А. Факторы самоактуализации личности. Философия образования. 2010. № 2 (31). С. 228-233.

8. Старинська Н. В. Особливості самоактуалізації майбутніх психологів у процесі професійної підготовки. К.: «Інтерсервіс», 2015. 178 с.

9. Краснощеченко И. П. Акмеологическая концепция становлення и развития профессиональной субъктности будущих психологов: дисс. ... доктора психол. наук: 19.00.13 / Московский город. псих.-пед. ун-тет. Москва, 2012. 362 с.

10. Митник О. Розвиток суб'єктності практичного психолога у процесі професійної підготовки. Рідна школа. 2014. Вип. 4-5 (квітень-травень). С. 37-40.

11. Мілютіна К. Л. Динаміка професійної компетентності практичних психологів у процесі перенавчання. Педагогічний прочес: теорія і практика. Педагогіка. Психологія. 2005. Вип. 3. С. 363-367.

12. Пророк Н. В. Психолог: професійно важливі якості. Психологія. 2002. Вип. 1. С. 16-17.

13. Дьяконов Г. В. Психологічні особливості професійної мотивації майбутніх психологів. Наукові записки Кіровоградського державного педагогічного університету імені Володимира Винниченка. Сер.: Педагогічні науки. 2012. Вип. 106. С. 39-48.

\section{References:}

1. Panok, V. (Ed.). (2006). Osnovy praktychnoi psykholohii [Fundamentals of practical psychology]. Kyiv: Lybid [in Ukrainian].

2. Panok, V. (2002). Reformuvannia zmistu, form i metodiv pidhotovky praktykuiuchykh psykholohiv yak nahalna vymoha suspilnoi praktyky [Reforming the content, forms and methods of training practicing psychologists as an urgent requirement of social practice]. Problemy pidhotovky $i$ 
pidvyshchennia kvalifikatsii praktychnykh psykholohiv u vyshchykh navchalnykh zakladakh Problems training and advanced training of practical psychologists in higher educational institutions, issue 11, 18-28 [in Ukrainian].

3. Story, G.V. (2014). Formirovanie sistemy tsennostnyh orientatsiy budushchih prakticheskih psihologov $\mathrm{v}$ protsesse obucheniya [Formation of a system of value orientations of future practical psychologists in the training process]. Extended abstract of candidate's thesis. Stavropol [in Russian].

4. Maslow, A. (2002). Po napravleniyu $k$ psihologii bytiya [Towards a psychology of being]. Moscow: Izdatelstvo Eksmo-Press [in Russian].

5. Bodalev, A.A. (2003). Kak stanovyatsya velikimi ili vydayushchimisya [How to become great and outstanding]. Moscow: Izdatelstvo Instituta Psihoterapii [in Russian].

6. Sadova, M.A. (2010). Psykholohichni skladovi potentsialu samorealizatsii osobystosti [Psychological constituents of potential of individual self-realization]. Extended abstract of candidate's thesis. Lutsk [in Ukrainian].

7. Tetenov, S.A. (2010). Faktory samoaktualizatsii lichnosti [Factors of self-actualization of personality]. Filosofiya obrazovaniya - Philosophy of education, 2 (31), 228-233 [in Russian].

8. Starynska, N.V. (2015). Osoblyvosti samoaktualizatsii maibutnikh psykholohiv u protsesi profesiinoi pidhotovky [Peculiarities of self-actualization of future psychologists in the process of vocational training]. Kyiv: «Interservis» [in Ukrainian].

9. Krasnoshchechenko, I.P. (2012). Akmeologicheskaya kontseptsiya stanovleniya i razvitiya professionalnoy sub'ektnosti budushchih psihologov [Acmeological concept of the formation and development of professional subjectivity of future psychologists]. Doctor's thesis. Moscow [in Russian].

10. Mytnyk, O. (2014). Rozvytok subiektnosti praktychnoho psykholoha u protsesi profesiinoi pidhotovky [Development of subjectity of future practical psychologist in the process of vocational training]. Ridna shkola - Native school, issue 4-5, 37-40 [in Ukrainian].

11. Miliutina, K.L. (2005). Dynamika profesiinoi kompetentnosti praktychnykh psykholohiv $\mathrm{u}$ protsesi perenavchannia [Dynamics of professional competence of practical psychologists in the process retraining]. Pedahohichnyi protses: teoriia $i$ praktyka. Pedahohika. Psykholohiia Pedagogical process: theory and practice. Pedagogy. Psycology, issue 3, 363-367 [in Ukrainian].

12. Prorok, N.V. (2002). Psykholoh: profesiino vazhlyvi yakosti [A psychologist: professionally important qualities]. Psykholohiia - Psychology, issue 1, 16-17 [in Ukrainian].

13. Diakonov, H.V. (2012). Psykholohichni osoblyvocti profesiinoi motyvatsii maibutnikh psykholohiv [Psychological features of professional motivation of future psychologists]. Naukovi zapysky Kirovohradskoho derzhavnoho pedahohichnoho universytetu imeni Volodymyra Vynnychenka. Ser.: Pedahohichni nauky - Academic notes of Kirovohrad Volodymyr Vynnychenko State Pedagogical University. Series: Pedagogical sciences, issue 106, $39-48$ [in Ukrainian]. 